\title{
EDITORIAL
}

\section{GESTÃO AMBIENTAL URBANA E SUSTENTABILIDADE}

A Revista LABVERDE n`8 apresenta como tema central as questões de 'gestão ambiental urbana e sustentabilidade'. Como se pode observar, os artigos deste número apresentam trabalhos que delineiam conceitos de gestão ambiental nas várias escalas do território, tendo por filtro as necessidades e aspirações de vários setores socioculturais, não só da cidade, como também da macrometrópole de São Paulo.

Dessa forma a LABVERDE apresenta os primeiros três artigos girando em torno dessa temática e abrangendo a escala metropolitana, a começar pelo artigo de SCHUTZER defendendo uma abordagem preliminar sobre a natureza da 'gestão ambiental do território urbanizado' e onde estará o 'lócus' das ações vinculadas ao conceito de 'infraestrutura verde'. Segue-se o trabalho de FERREIRA questionando a operacionalização do Rodoanel Metropolitano Mário Covas que, segundo o autor, devido à adoção de um modelo operacional inadequado compromete seu próprio desempenho e degrada o ambiente construído. O texto de LIMA discute a possibilidade de uma reintegração territorial por meio de um planejamento ambiental orientado por uma infraestrutura verde no caso do Bairro dos Alvarenga, em São Bernardo do Campo, o qual, hoje cortado por rodovias vitais aos serviços metropolitanos, apresenta graves problemas de integração sócio-ambiental e de mobilidade, decorrentes do esfacelamento do seu tecido urbano pela infraestrutura viária existente.

No quarto artigo, BONZI discute sobre o modelo urbanístico da segunda metade do século XX que desconsiderou a questão das águas urbanas como elementos integrantes da paisagem, e investiga córregos que desapareceram da visão por ocasião da implantação do projeto urbanístico da Cidade Universitária Armando de Salles Oliveira, no Bairro do Butantã.

SATIRO, no quinto artigo, nos fala do conceito de 'gerontologia ambiental' e projetos habitacionais para idosos do Estado de São Paulo, os quais, segundo a autora, fazem compreender novas possibilidades projetuais que colaboram para a qualidade de vida e a sustentabilidade das construções, a partir da definição concreta de conceitos como 'acessível', 'adaptado' e 'adaptável'. 
HANNES apresenta, no sexto artigo, az uma leitura do projeto do Parque da Juventude, localizado no Bairro do Carandiru, sob a ótica ambiental, tratando do seu processo de criação e projeto, bem como da sua inserção no território da cidade de São Paulo, discutindo possíveis potencialidades que o local apresenta para o desenvolvimento de um 'desenho' e 'planejamento ambiental sustentáveis'.

Na seção Entrevista, o arquiteto Luis Eduardo Brettas refere-se ao trabalho da 'São Paulo Urbanismo', que desde abril de 2013 iniciou um "diálogo aberto" com um grande número de pessoas, de diversos níveis de conhecimento e procedentes de diversas áreas de atuação, chegando a uma análise, um diagnóstico e um programa de intervenção nos espaços públicos da cidade, em atendimento ao programa de metas da Prefeitura Municipal de São Paulo, onde ganha ênfase o "Projeto de Requalificação do Vale do Anhangabaú", contando .com a consultoria do escritório 'Gehl Architects'.

Neste número, na seção Depoimento-1, Fernando de Mello Franco, Secretário Municipal de Desenvolvimento Urbano e Presidente da São Paulo Urbanismo, defende as idéias de 'inovação e processos colaborativos' na renovação do Centro de São Paulo no "Novo Projeto para o Vale do Anhangabaú", inspirado em conceitos metodológicos de requalificação urbana do arquiteto Jan Gehl, tendo por cenário a "Copa do Mundo", a "FIFA Fan Fest" e outros eventos. Em contrapartida, no Depoimento-2, Marco Antonio Ramos de Almeida, superintendente-geral da Associação Viva o Centro, faz uma crítica severa ao "Novo Projeto para o Vale do Anhangabaú", detalhando seus motivos.

No mês de abril próximo passado foi realizado o segundo encontro do LABVERDE com os coletivos OCUPE \& ABRACE e RIOS E RUAS, para apresentação do "Estudo Preliminar de Requalificação da Praça da Nascente", que contou com a colaboração dos escritórios 'Patrícia Akinaga Arquitetura Paisagística' e 'Amima Arquitetura', cujo acontecimento motivou a capa da Revista LABVERDE N08, e o relato de José Otávio Lotufo na seção Eventos desta edição.

Espero que os leitores façam uma boa leitura.

\section{MARIa de Assunção Ribeiro Franco}

Editora da Revista LABVERDE

São Paulo, junho de 2014. 